\title{
Brain natriuretic peptide for prediction of mortality in patients with sepsis: a systematic review and meta-analysis
}

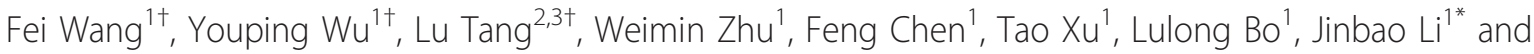
Xiaoming Deng ${ }^{1 *}$

\begin{abstract}
Introduction: Early identification of septic patients at high risk of dying remains a challenge. The prognostic role of brain natriuretic peptide (BNP) or N-terminal pro-B-type natriuretic peptide (NT-proBNP) in septic patients remains controversial. The purpose of this systematic review and meta-analysis was to investigate the value of elevated BNP or NT-proBNP in predicting mortality in septic patients.

Methods: PubMed, Embase and the Cochrane Central Register of Controlled Trials were searched (up to February 18, 2011). Studies were included if they had prospectively collected data on all-cause mortality in adult septic patients with either plasma BNP or NT-proBNP measurement. Studies that failed to construct a $2 \times 2$ table of results were excluded. Two authors independently determined the validity of included studies and extracted data.

Results: 12 studies with a total of 1,865 patients were included. Elevated natriuretic peptides were significantly associated with increased risk of mortality (odds ratio (OR) 8.65, 95\% confidence interval (Cl) 4.94 to $15.13, P<$ 0.00001). The association was consistent for BNP (OR 10.44, 95\% Cl 4.99 to 21.58, $P<0.00001)$ and NT-proBNP (OR $6.62,95 \% \mathrm{Cl} 2.68$ to $16.34, P<0.0001)$. The pooled sensitivity, specificity, positive likelihood ratio, and negative likelihood ratio were $79 \%$ (95\% Cl 75 to 83), 60\% (95\% Cl 57 to 62), 2.27 (95\% Cl 1.83 to 2.81) and 0.32 (95\% Cl 0.22 to 0.46$)$, respectively.

Conclusions: Our results suggested that an elevated BNP or NT-proBNP level may prove to be a powerful predictor of mortality in septic patients. Future larger and more adequately powered prospective studies are warranted to clarify the assay standardization, the optimal cut-off, and the prognostic value of BNPs in conjunction with other biomarkers.
\end{abstract}

\section{Introduction}

Sepsis is a leading cause of death in critically ill patients despite improvements in antimicrobial therapy and supportive care [1]. The septic response is an extremely complex chain of events involving inflammatory and anti-inflammatory processes, hormonal and cellular reactions, and circulatory abnormalities [2,3]. Early identification of patients at high risk of dying after intensive care unit (ICU) admission may help determine therapeutic interventions, such as changes in therapeutic

\footnotetext{
*Correspondence: lijinbaoshanghai@163.com; deng_x@yahoo.com

† Contributed equally

'Department of Anesthesiology and Critical Care, Changhai Hospital, Second Military Medical University, Shanghai, China

Full list of author information is available at the end of the article
}

protocols or further diagnostic procedures aiming at preventing shock and multiple organ failure with all their sequels that could have an impact on patients' outcome [4-6]. Therefore, there is a need for a fast simple and cost-effective method to enhance risk stratification in septic patients.

Brian natriuretic peptide (BNP) and its inactive cleavage product N-terminal fragment (NT-proBNP) were secreted into the blood in response to atrial or ventricular wall stretch [7], or myocardial ischemia [8] by cardiomyocytes. The half-life of BNP is approximately 20 minutes, and that of NT-proBNP is 1-2 hours [9]. The term BNPs will be used to represent either BNP or NT-proBNP throughout the rest of the paper unless otherwise stated.
C Biomed Central

() 2012 Wang et al.; licensee BioMed Central Ltd. This is an open access article distributed under the terms of the Creative Commons Attribution License (http://creativecommons.org/licenses/by/2.0), which permits unrestricted use, distribution, and reproduction in any medium, provided the original work is properly cited. 
BNPs have been found to be useful markers in the diagnosis, management and prognosis of patients with congestive heart failure [10]. In addition, BNPs are powerful predictors of death and major adverse cardiovascular events in patients with stable coronary disease [11], acute coronary syndromes [12] and pulmonary embolism, [13] and those who undergo noncardiac surgery [14]. Several prospective studies have been performed to investigate the potential role of BNPs in predicting mortality in septic patients, but they had limited numbers of patients, used different cut-off points and involved different clinical endpoints. In the present study, we made a systematic review and meta-analysis to evaluate the correlation between elevated levels of BNPs and death in septic patients.

\section{Materials and methods}

This systematic review and meta-analysis was performed according to the guidelines of Meta-analysis of Observational Studies in Epidemiology [15].

\section{Study outcome}

The aim of this meta-analysis was to see whether elevated BNPs could predict all-cause mortality in adult patients with sepsis.

\section{Search strategy and eligibility assessment}

Pubmed, Embase and the Cochrane Central Register of Controlled Trials (up to February 18, 2011) were searched by using Exploded Medical Subject Headings and the appropriate corresponding keywords, "Brain natriuretic peptide", "B-type natriuretic peptide", "BNP", "pro-brain natriuretic peptide", "amino terminal probrain natriuretic peptide", "amino terminal pro-BNP", "N-terminal pro B-type natriuretic peptide", "NTproBNP", "natriuretic peptide" AND "sepsis", "septicemia", "septicaemia", "septic". No language restrictions were applied. Additionally, the reference lists of the original studies and previous review articles were handsearched to identify other potentially eligible studies.

Two authors independently determined the eligibility of all studies identified in initial research. Studies were included if they prospectively collected data on all-cause mortality in adult septic patients with either plasma BNP or NT-proBNP measurement. Studies where a $2 \times 2$ table of results could not be constructed were excluded. In case of disagreements, a third author was consulted. Agreement regarding study inclusion was assessed using the Cohen K statistic [16].

\section{Data extraction and quality assessment}

Two authors independently extracted the following descriptive data from all eligible studies: study design, sample size, patient population, inclusion/exclusion criteria, diagnostic criteria for sepsis, severe sepsis and septic shock, follow-up period, completeness of followup, outcome assessment, marker evaluated (i.e., BNP or NT-proBNP), assay manufacturer, the optimal cut-off point, timing of BNP measurement, and the proportion of patients with an elevated BNP measurement. If data needed clarification or were not presented in the publication, the original authors were contacted by E-mail. Extracted data were entered into Microsoft Office Excel 2007 and checked by the third author. Any disagreement was solved by discussion.

Given that the eligible studies were of a prognostic nature, methodological and reporting quality was assessed according to the Quality Assessment of Diagnostic Accuracy Studies checklist (see Additional file 1) [17].

\section{Statistical analysis}

Results were analyzed using Review Manager 5.1 (Cochrane Collaboration, Oxford, UK) and Meta-Disc 1.4 [18] (Clinical Biostatistics, Ramon y Cajal Hospital, Madrid, Spain). As individual studies used different cutoff points for defining elevated BNPs, Spearman's correlation coefficient between sensitivity and specificity was calculated to detect the presence of a threshold effect, where variations in sensitivity and specificity were related to differences in the cut-off point used to define an elevated BNPs level [19]. If there was no evidence of a threshold effect, then summary estimates, including odds ratio (OR), sensitivity, specificity, positive likelihood ratio, and negative likelihood ratio, were calculated using the random-effects model based on DerSimonian and Lair's meta-analytic statistical method [20]. In case a study provided multiple cut-off points for BNPs analysis, the point giving the maximum overall accuracy was chosen. In the case of analyses with empty cells, 0.5 was added to all cells to avoid computational errors. Publication bias was assessed by visually inspecting funnel plot. A p value of less than 0.05 was considered statistically significant.

Cochrane's $\mathrm{Chi}^{2}$ test and $\mathrm{I}^{2}$ test for heterogeneity were used to assess inter-study heterogeneity [21]. The $\mathrm{Chi}^{2}$ test assesses whether observed differences in results are compatible with chance alone and the $\mathrm{I}^{2}$ describes the percentage of the variability in effect estimates that is due to heterogeneity rather than sampling error. Statistically significant heterogeneity was considered present at $\mathrm{Chi}^{2}$ $P<0.10$ and $\mathrm{I}^{2}>50 \%$. To explore the heterogeneity observed, sensitivity analyses were performed by sequential exclusion of each study. A prior subgroup analyses to explain significant heterogeneity were: 1 ) BNPs type (BNP versus NT-proBNP); and 2) blinding of BNPs measurement to the outcome (yes versus no). Single covariate random-effects meta-regression (inverse variance weights) was also used to explore sources of variation. 
Patient population (sepsis versus severe sepsis or septic shock), the underlying diseases (inclusion versus exclusion of preexisting conditions known to increase BNPs levels), optimal timing of BNPs measurement, and mortality were considered as variables.

\section{Results}

Our initial search yielded 484 citations, of which 464 were eliminated for various reasons based on the title and abstract. The full texts of the remaining 20 articles were scrutinized for further evaluation. Twelve studies [22-33] fulfilled our eligibility criteria and were finally included (Figure 1). The Cohen statistic $\mathrm{K}$ for agreement on study inclusion was 0.90 .

\section{Characteristics of included studies}

The included studies were published from 2004 to 2011 and all were prospective cohort studies (Table 1). Among them, seven studies [26-29,31-33] were conducted in Europe, three $[24,25,30]$ in Asia, one [22] in North America, and one [23] in Australasia. Two studies [22,28] were multicenter studies and one study [23] reported both BNP and NT-proBNP. All studies but one [24] were published in English. The mean age of the patients varied between 55 and 69 years and the proportion of men ranged from 47 to $82 \%$. The subject population varied across studies: three $[22,25,26]$ included patients with sepsis, and nine [23,24,27-33] with severe sepsis or septic shock. The selected studies were performed in various departments, including emergency department, medical ICU, surgical ICU and general ICU. Nine studies [22,24,26,27,29-33] excluded patients with preexisting conditions known to increase BNPs levels. Follow-up periods differed across studies, including 28 days, ICU stay and hospital stay.

\section{BNPs measurements}

Among the included studies, BNP measurement was performed in eight $[22-27,30,33]$ and NT-proBNP in five $[23,28,29,31,32]$ (Table 2). In the BNP studies, four $[22,23,25,27]$ used immunofluorescence assay of Triage BNP test (Biosite Diagnostics, San Diego, CA), three $[26,30,33]$ utilized immunoradiometric assay (ShionoraBNP), and one [24] did not report the method of BNP assay. In the NT-proBNP studies, four [23,28,29,31] used an electrochemiluminescence immunoassay performed on a Roche analyzer (Roche Diagnostics), and one study [32] utilized an enzyme immunoassay (Biozol). Among the included studies, receiver operating characteristic (ROC) curve was performed to retrospectively determine the optimal cut-off point with regard to 28-day mortality in seven studies [24-27,30,32,33], ICU mortality in two studies [29,31], in-hospital mortality in two study [23,28], and a composite outcome of in-hospital mortality, severe sepsis, or septic shock in one study [22]. Normal BNPs levels were defined as levels beneath or equal to the optimal cutoff points. The optimal cut-off points varied greatly across studies, from $32.1 \mathrm{pg} / \mathrm{ml}$ to $681.4 \mathrm{pg} / \mathrm{ml}$ for BNP, and from $400 \mathrm{pg} / \mathrm{ml}$ to $13,600 \mathrm{pg} / \mathrm{ml}$ for NT-proBNP. There were wide variations about the optimal timing of BNP measurement (six studies [22,24-26,28,31]: the day on admission; five studies [23,29,30,32,33]: day 2 after admission; one study [27]: day 5 after admission).

\section{Study quality and publication bias}

All the twelve included studies fulfilled the requirements of a representative spectrum of patients, and clearly described selection criteria, outcome verification in the whole cohort, equal outcome evaluation regardless of the BNPs results, sufficient description of BNPs measurement for replication and availability of clinical data. Four studies $[22,28,30,33]$ stated that the BNPs results were interpreted without knowledge of outcome assessment. Because the target condition was mortality, outcome assessment was unlikely to be influenced by knowledge of the BNPs results. No patient was lost to follow-up.

Regarding the predictive value of elevated BNPs for mortality, there was no evidence of significant publication bias by inspection of the funnel plot (Figure 2).

\section{Predictive value of BNPs on all-cause mortality}

Overall, 349 (37.6\%) of the 929 patients with elevated BNPs died vs 90 (9.4\%) of the 957 patients with normal BNPs. Spearman's correlation coefficient between sensitivity and specificity was $-0.132(P=0.667)$, suggesting no evidence of a threshold effect. Therefore, pooled estimates were calculated. Elevated BNPs were associated with a significantly increased risk of all-cause mortality (OR 8.65, $95 \%$ confidence interval (CI) 4.94 to $15.13, P<0.00001$, Figure 3$)$ with significant heterogeneity $\left(\mathrm{I}^{2}=64 \%, P=\right.$ $0.001)$. The pooled sensitivity and specificity were $79 \%$ (95\% CI 75 to 83, Figure 4) and 60\% (95\% CI 57 to 62, Figure 5), respectively. The summary positive and negative likelihood ratios were 2.27 (95\% CI 1.83 to 2.81, Figure 6) and 0.32 (95\% CI 0.22 to 0.46 , Figure 7), respectively.

The prior sensitivity analysis suggested that the heterogeneity was accounted for by two studies which had the minimum [28] and maximum [26] areas under the ROC curve. With the two studies excluded, the pooled OR was not significantly altered (OR 8.67, 95\% CI 5.46 to 13.77 , $P<0.00001)$ with no significant heterogeneity $\left(\mathrm{I}^{2}=33 \%\right.$, $P=0.13)$. Subgroup analyses suggested that the association between elevated BNPs and increased risk of all-cause mortality was consistent for BNP (OR 10.44, 95\% CI 4.99 to $\left.21.58, P<0.00001 ; \mathrm{I}^{2}=64 \%\right)[22-27,30,33]$ and NTproBNP (OR 6.62, 95\% CI 2.68 to $16.34, P<0.0001 ; \mathrm{I}^{2}=$ $57 \%$ ) $[23,28,29,31,32]$, as well as blinding (OR 3.83, 95\% CI 2.52 to $\left.5.82, P<0.00001 ; \mathrm{I}^{2}=0 \%\right)[22,28,30,33]$ and no blinding (OR 14.24, 95\% CI 6.56 to $30.93, P<0.00001$; 


\section{Excluded for duplication}

\section{Potentially relevant studies}

\section{Excluded by screening of titles or abstracts}

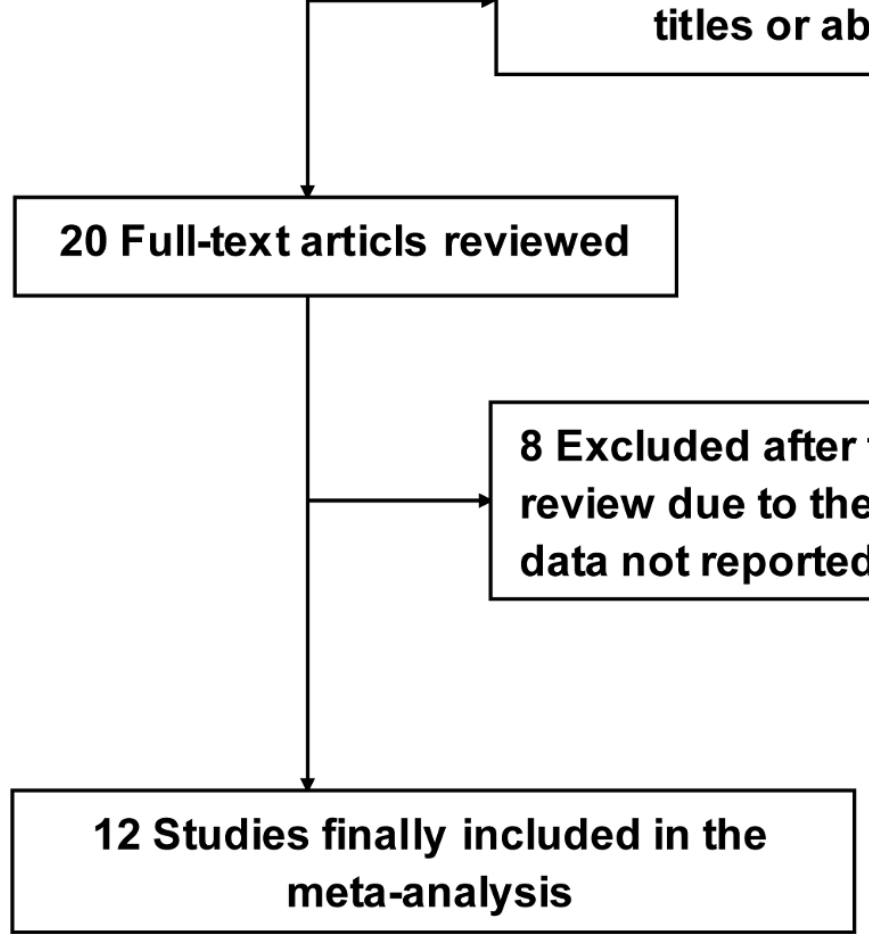

Figure 1 Flow-chart of study selection.

$\left.\mathrm{I}^{2}=63 \%\right)[23-27,29,31,32]$ of BNPs measurement to the outcome. According to our priori hypothesis, meta-regression analyses showed that patient population $(P=0.76)$, the underlying diseases $(P=0.12)$, optimal timing of BNPs measurement $(P=0.89)$, and mortality $(P=0.10)$ did not explain the demonstrated heterogeneity, respectively.

\section{Discussion}

The present meta-analysis showed that elevated BNPs were associated with a significantly increased risk of mortality in patients with sepsis. The finding is consistent for both BNP and NT-proBNP. As such, measurement of BNPs may be a simple method of risk stratification in septic patients.

BNPs elevation in patients with sepsis can be considerably high, even though cardiac depression is not obvious. A retrospective study [34] suggested that BNPs level in septic patients with preserved systolic left ventricular function could be as high as that in patients admitted to the hospital with congestive heart failure because of severely impaired systolic left ventricular function. Aside from neurohormonal activation, several 
Table 1 Characteristics of included studies

\begin{tabular}{|c|c|c|c|c|c|c|c|c|c|}
\hline Marker & Study & Country & Setting & Population & NO. & $\begin{array}{c}\text { Male } \\
(\%)\end{array}$ & Age (year) & Outcome & $\begin{array}{c}\text { Mortality } \\
(\%)\end{array}$ \\
\hline \multirow{5}{*}{$\begin{array}{l}\text { NT- } \\
\text { proBNP }\end{array}$} & Varpula 2007 [28] & Finland & $24 \mathrm{ICUs}$ & Severe sepsis or septic shock & 254 & 69 & $59 \pm 15$ & In-hospital mortality & 26 \\
\hline & Mokart 2007 [29] & France & ICU & $\begin{array}{c}\text { Cancer patients developing septic } \\
\text { shock }\end{array}$ & 51 & 63 & $\begin{array}{l}56(50- \\
68)^{+}\end{array}$ & ICU mortality & 51 \\
\hline & Roch 2005 [31] & France & General ICU & Septic shock & 39 & 82.1 & $63 \pm 12$ & ICU mortality & 56 \\
\hline & $\begin{array}{l}\text { Brueckmann } 2005 \\
{[32]}\end{array}$ & Germany & Three departments in one hospital $\left.\right|^{\ddagger}$ & Severe sepsis & 57 & 74 & $55.0 \pm 16.3$ & 28-day mortality & 28 \\
\hline & $\begin{array}{c}\text { Sturgess 2010b* } \\
{[23]}\end{array}$ & Australia & ICU & Septic shock & 21 & 61.9 & $65 \pm 17$ & In-hospital mortality & 29 \\
\hline \multirow[t]{8}{*}{ BNP } & Perman 2011 [22] & USA & Emergency departments of 10 centers & Clinical evidence of sepsis & 825 & 49 & $53.5 \pm 19.6$ & $\begin{array}{l}\text { A composite of } \\
\text { events } \$\end{array}$ & 6.6 \\
\hline & Zhao 2009 [24] & China & Surgical ICU & Severe sepsis or septic shock & 102 & 53.9 & - & 28-day mortality & 38.2 \\
\hline & Chen 2009 [25] & China & Emergency department & Sepsis & 327 & 60.6 & $69.5 \pm 13.4$ & 28-day mortality & 37.3 \\
\hline & Yucel 2008 [26] & Turkey & General ICU & Sepsis & 40 & - & - & 28-day mortality & 50 \\
\hline & Post 2008 [27] & Germany & $\mathrm{ICU}$ & Septic shock & 93 & 55 & $\begin{array}{l}65(53- \\
73.5)^{+}\end{array}$ & 30-day mortality & 40.9 \\
\hline & Ueda 2006 [30] & Japan & $\begin{array}{c}\text { Department of Emergency and Critical Care } \\
\text { Medicine }\end{array}$ & Septic shock & 22 & 77.3 & $62.5 \pm 19.3$ & 28-day mortality & 54.5 \\
\hline & $\begin{array}{c}\text { Charpentier } 2004 \\
{[33]}\end{array}$ & France & Medical ICU & Severe sepsis or septic shock & 34 & 47.1 & $56 \pm 15.7$ & 28-day mortality & 29 \\
\hline & $\begin{array}{c}\text { Sturgess 2010a* } \\
{[23]}\end{array}$ & Australia & ICU & Septic shock & 21 & 61.9 & $65 \pm 17$ & In-hospital mortality & 29 \\
\hline
\end{tabular}

BNP $=$ brain natriuretic peptide, NT-proBNP $=$ N-terminal pro-B-type natriuretic peptide, ICU $=$ intensive care unit. ${ }^{*}$ The study reported both BNP (Sturgess $\left.2010 \mathrm{a}\right)$ and NT-proBNP $($ Sturgess $2010 \mathrm{~b}) .{ }^{\dagger}$ Median $(25$ th 75th percentiles). " Dash indicates that information was not provided. ${ }^{\S}$ Events include in-hospital mortality, severe sepsis, or septic shock within 30 days following presentation. ${ }^{\ddagger}$ Anesthesiology Department, Cardiosurgical Anesthesiology Department, and Internal Medicine Department. 
Table 2 NT-proBNP and BNP measurements

\begin{tabular}{|c|c|c|c|c|c|c|c|}
\hline Marker & Study & Assay $^{\dagger}$ & Optimal Timing & $\begin{array}{l}\text { Cut-off } \\
\text { Point } \\
\text { (pg/ml) }\end{array}$ & $\begin{array}{l}\text { Sensitivity/ } \\
\text { Specificity }\end{array}$ & $A \cup C^{\pi}$ & $\begin{array}{l}\text { Proportion of Elevated } \\
\text { BNPs (\%) }\end{array}$ \\
\hline \multirow[t]{5}{*}{$\begin{array}{c}\text { NT- } \\
\text { proBNP }\end{array}$} & $\begin{array}{c}\text { Varpula } 2007 \\
\text { [28] }\end{array}$ & $\begin{array}{c}\text { Roche, Elecsys } 2010 \\
\text { analyzer }\end{array}$ & On admission & 7090 & $58 / 66$ & 0.631 & 40.6 \\
\hline & Mokart 2007 [29] & $\begin{array}{c}\text { Roche, Elecsys } 2010 \\
\text { analyzer }\end{array}$ & Day 2 after admission & 6624 & $86 / 77$ & 0.87 & 54.9 \\
\hline & Roch 2005 [31] & $\begin{array}{c}\text { Roche, Elecsys } 2010 \\
\text { analyzer }\end{array}$ & $\begin{array}{c}\text { Within } 24 \text { hours after } \\
\text { admission }\end{array}$ & 13600 & $73 / 83$ & 0.8 & 48.7 \\
\hline & $\begin{array}{l}\text { Brueckmann } \\
2005 \text { [32] }\end{array}$ & $\begin{array}{l}\text { Enzyme immunoassay } \\
\text { (Biozol) }\end{array}$ & Day 2 after admission & 11900 & $50 / 90$ & 0.68 & 21.1 \\
\hline & $\begin{array}{c}\text { Sturgess 2010b* } \\
{[23]}\end{array}$ & $\begin{array}{c}\text { Roche, Elecsys } 2010 \\
\text { analyzer }\end{array}$ & $\begin{array}{c}\text { Within } 72 \text { hours after } \\
\text { admission }\end{array}$ & 400 & $83 / 40$ & 0.67 & 66.7 \\
\hline \multirow[t]{8}{*}{ BNP } & $\begin{array}{c}\text { Perman } 2011 \\
{[22]}\end{array}$ & Biosite Diagnostics, Triage & On admission & 49 & $63 / 69$ & 0.69 & 47.6 \\
\hline & Zhao 2009 [24] & $\begin{array}{l}\text { Immunofluorescence } \\
\text { assay }^{\mp}\end{array}$ & $\begin{array}{l}24 \text { hours after } \\
\text { admission }\end{array}$ & 681.4 & $91.4 / 80.3$ & 0.915 & 47.1 \\
\hline & Chen 2009 [25] & Biosite Diagnostics, Triage & $\begin{array}{c}\text { Within } 24 \text { hours after } \\
\text { admission }\end{array}$ & 113 & $86 / 55$ & 0.737 & 32.1 \\
\hline & Yucel 2008 [26] & $\begin{array}{l}\text { Immunoradiometric assay, } \\
\text { Shionoria }\end{array}$ & On admission & 32.1 & $100 / 95$ & 0.99 & 52.5 \\
\hline & Post 2008 [27] & Biosite Diagnostics, Triage & Day 5 after admission & 121 & $76.3 / 52.7$ & 0.648 & 59.1 \\
\hline & Ueda 2006 [30] & $\begin{array}{l}\text { Immunoradiometric assay, } \\
\text { Shionoria }\end{array}$ & Day 2 after admission & 650 & $92 / 80$ & 0.85 & 59.1 \\
\hline & $\begin{array}{l}\text { Charpentier } \\
2004 \text { [33] }\end{array}$ & $\begin{array}{l}\text { Immunoradiometric assay, } \\
\text { Shionoria }\end{array}$ & Day 2 after admission & 190 & $70 / 67$ & 0.66 & 44.1 \\
\hline & $\begin{array}{c}\text { Sturgess 2010a* } \\
{[23]}\end{array}$ & Biosite Diagnostics, Triage & $\begin{array}{c}\text { Within } 72 \text { hours after } \\
\text { admission }\end{array}$ & 254 & $83 / 60$ & 0.76 & 52.4 \\
\hline
\end{tabular}

BNP = brain natriuretic peptide, NT-proBNP = N-terminal pro-B-type natriuretic peptide. *The study reported both BNP (Sturgess $2010 a)$ and NT-proBNP (Sturgess 2010b). ${ }^{\dagger}$ Manufacture and kind of assay. ${ }^{\ddagger}$ The manufacture was not reported. ๆ AUC indicates the area under the receiver operating characteristic curve.

mechanisms are likely to account for increased BNPs levels in sepsis, including sepsis-induced biventricular dilatation [35], the stimulation of lipopolysaccharide [36] or proinflammatory cytokines $[37,38]$, volume resuscitation [39] and sepsis-associated acute lung injury or acute respiratory distress syndrome [40]. Accordingly,

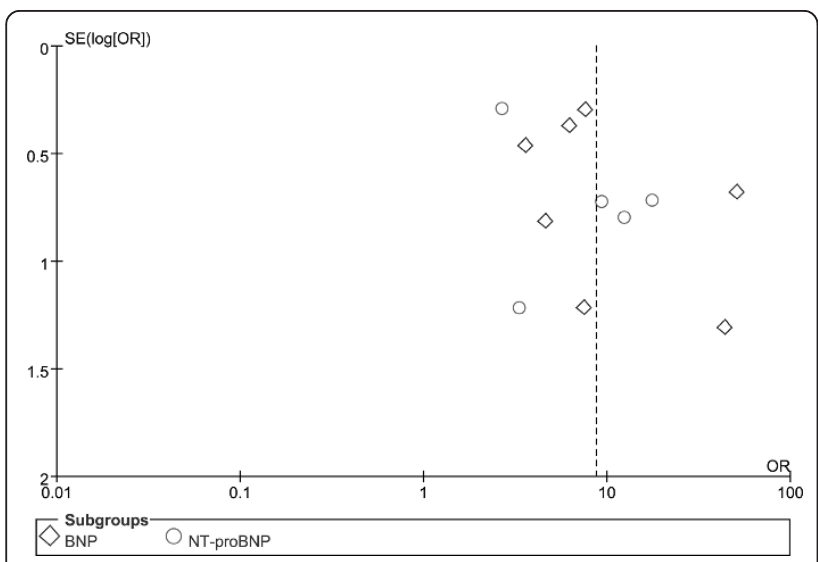

Figure 2 Funnel plot for the predictive value of elevated BNP or NT-proBNP for mortality in patients with sepsis. BNP = brain natriuretic peptide, NT-proBNP $=\mathrm{N}$-terminal pro-B-type natriuretic peptide. elevated BNPs level in the presence of sepsis does not essentially mean cardiac dysfunction due to low specificity, while normal BNPs level could be used to rule out the need for further cardiac investigation, unless there are other clinical grounds that strongly suspect a significant cardiac disorder.

Clinical severity scores such as acute physiology and chronic health evaluation (APACHE) II and sequential organ failure assessment (SOFA) scores have been validated for mortality risk stratification, but are unwieldy and tend to be used more for audit and research than clinical decision making in sepsis. A rapidly available biochemical test that provides similar or better prognostic information could therefore be useful, e.g. to help discussions about prognosis with patients' relatives and decisions regarding earlier interventions. Several studies $[25,41,42]$ showed that BNPs level was related to APACHE II and SOFA scores. In the present meta-analysis, two $[25,27]$ of the included studies directly compared the prognostic value of BNPs measurement $v s$ clinical severity scores and both suggested a better prognostic value of elevated BNPs in predicting mortality. Chen et al [25] reported a greater area under the ROC curve for the plasma BNP level than for APACHE II score (0.737 vs 0.664). Post et al [27] reported that regarding predicting 


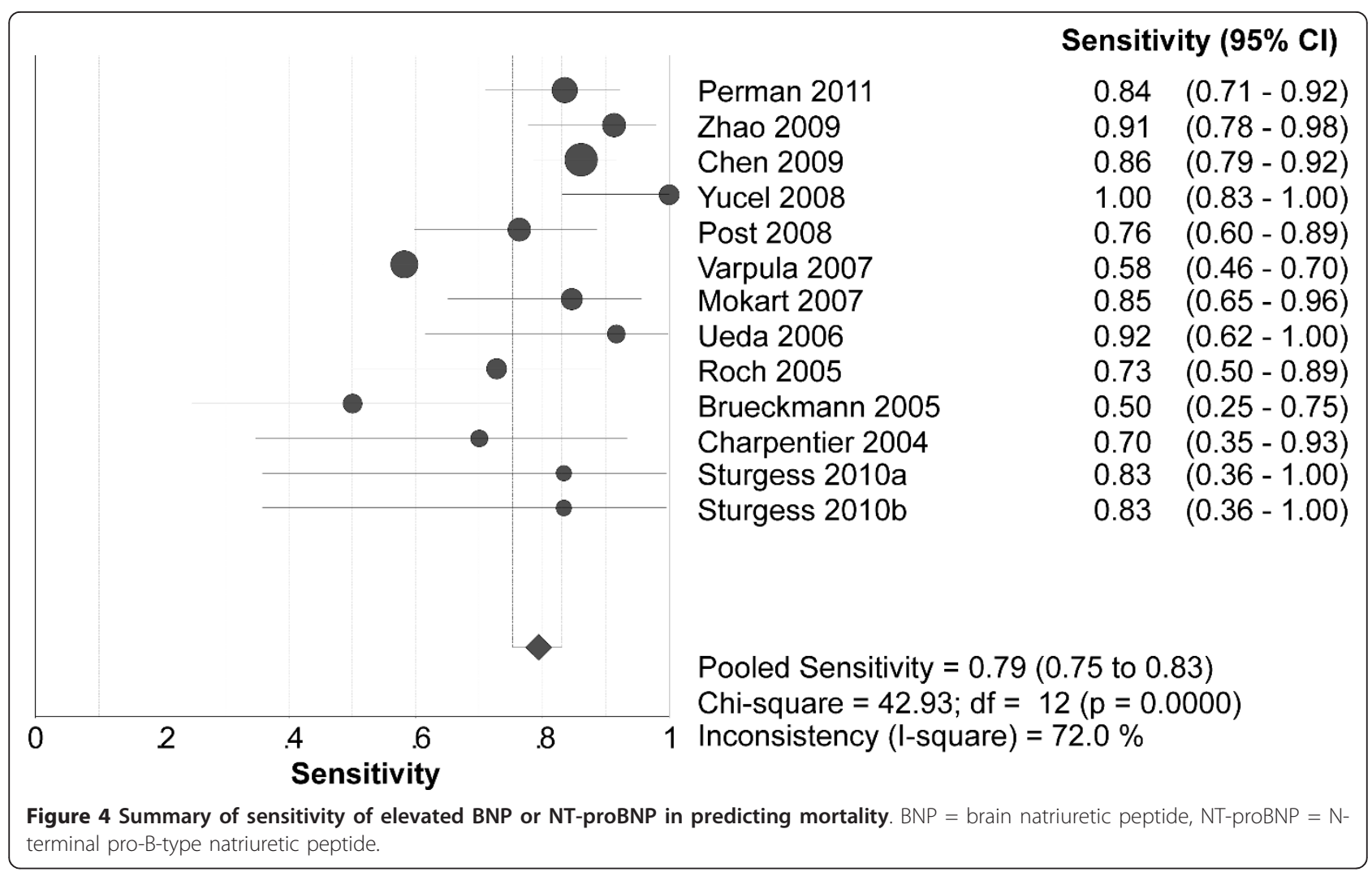

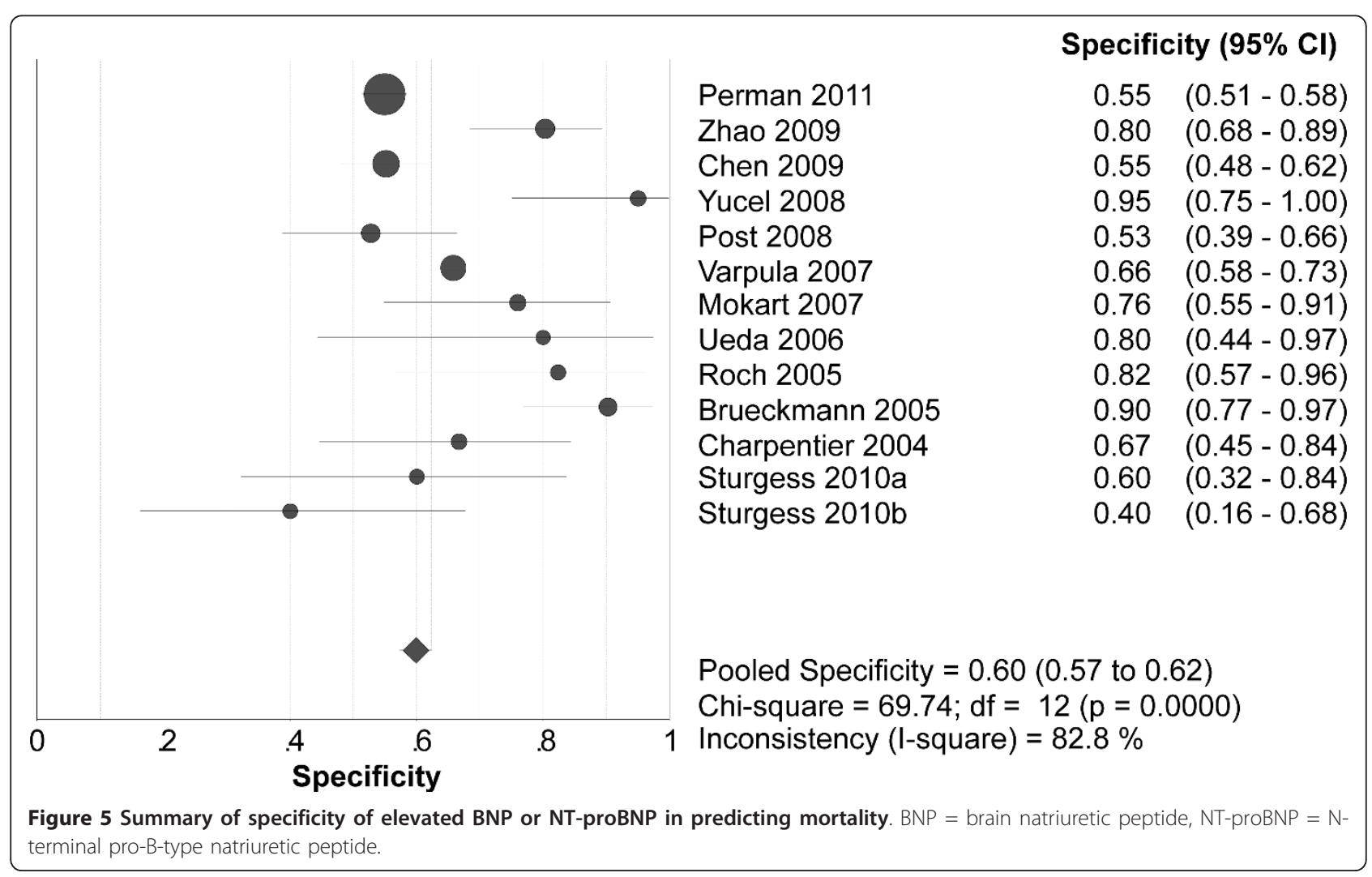




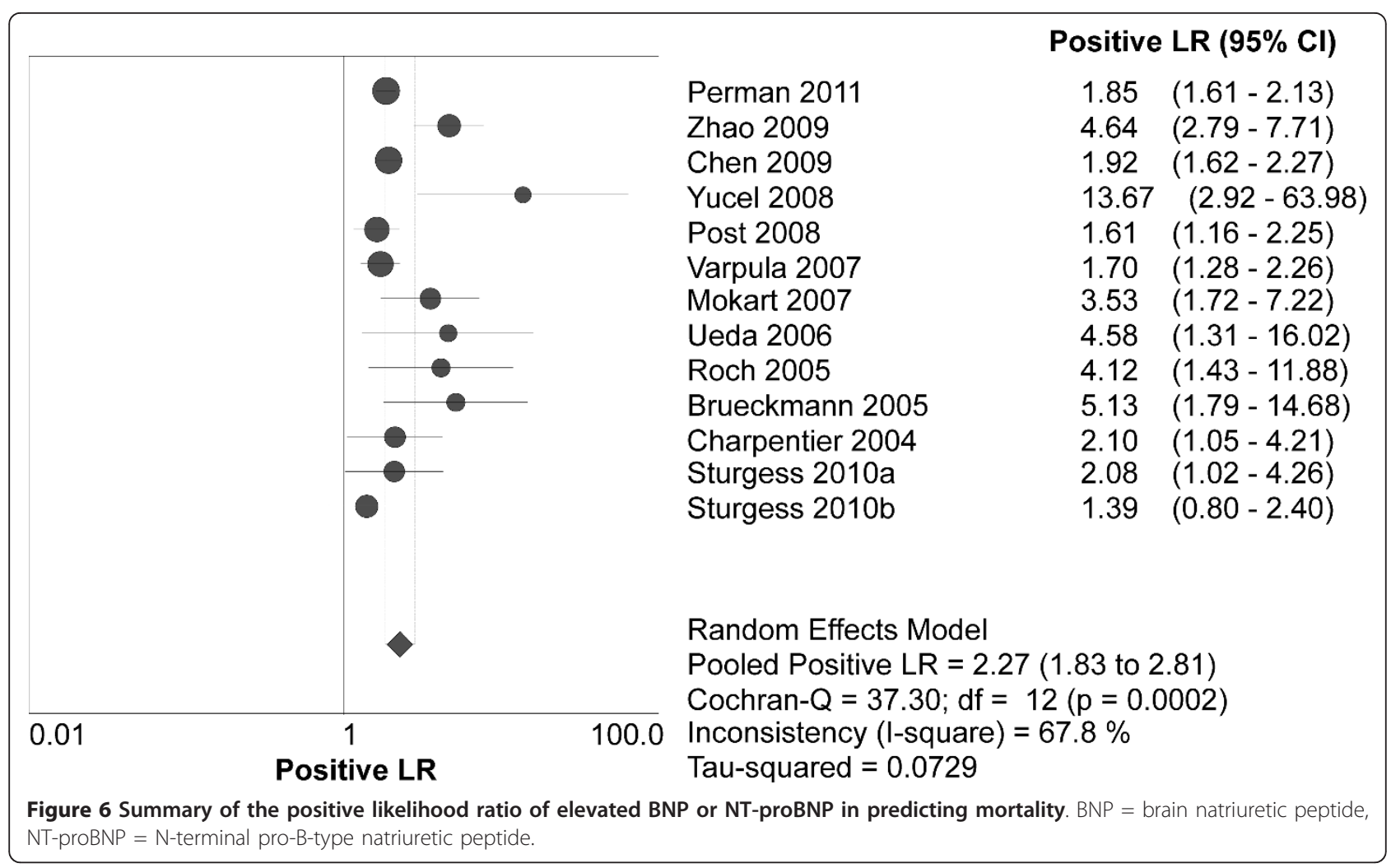

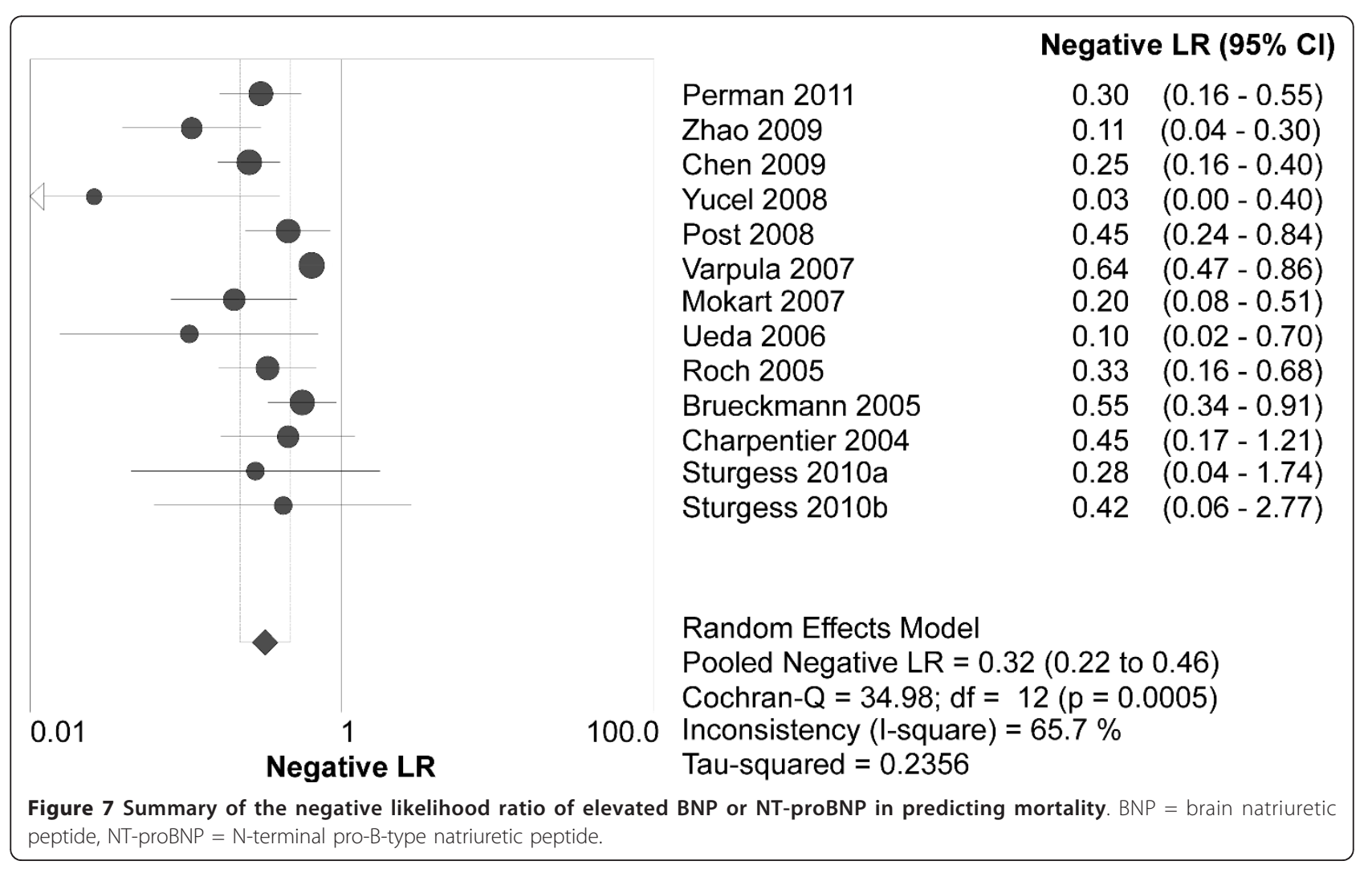


conducted in 90 Italian laboratories demonstrated that there were significant differences in analytical characteristics and measured values among the most popular commercial methods for BNP and NT-proBNP [48]. Therefore, clinicians should be very careful when comparing results obtained by laboratories that use different methods.

An important concern of using BNPs in septic patients is the impact of renal insufficiency on these tests. Acute renal insufficiency occurs in $11-16 \%$ of critically ill patients who presented with sepsis $[49,50]$. A study by Goei et al [51] suggested that NT-proBNP had more favorable discriminative value in patients with a glomerular filtration rate more than $90 \mathrm{~mL} / \mathrm{min} / 1.73$ $\mathrm{m}^{2}$, while it lost its prognostic value in patients with a glomerular filtration rate less than $30 \mathrm{~mL} / \mathrm{min} / 1.73 \mathrm{~m}^{2}$. No guidance on how BNPs values are adjusted for renal dysfunction is available today. Given the high prevalence and the impact of renal impairment on the BNPs values, it is preferable to adopt different cut-offs stratified by renal function in patients with sepsis.

There were several limitations in the present study. First, marked heterogeneity existed across the included studies in terms of population characteristics, BNPs assays, optimal cut-off point, follow-up period and definitions of endpoints. However, all the individual ORs favored the prognostic value of elevated BNPs in predicting mortality, indicating that the heterogeneity was entirely quantitative. Although there was uncertainty regarding the strength of the association, current evidence suggested that there was a significant correlation between an elevated BNPs level and an increased risk of mortality in septic patients. Second, the optimal timing of BNPs measurement varied across the studies, including the day on admission, and day 2 and day 5 after admission. It can be partly accounted for by the difficulty in determining the time of onset of sepsis and, hence, the time of patient recruitment. Third, it should be noted that the pooled estimates reflected unadjusted associations between BNPs and all-cause mortality. Five $[22,25,27,29,31]$ of the included studies provided adjusted ORs accounting for confounders. Pooled analysis of the adjusted ORs also suggested that elevated BNPs were correlated with a significantly increased risk of mortality in septic patients (random-effects model, OR $1.87,95 \%$ CI 1.30 to $2.69, P=0.001$ ). Because the ORs in the five studies were adjusted by different confounders with different regression models and the data reported on adjusted ORs were limited, we thus adopted unadjusted mortality data for pooled analyses in the present study. Finally, we could not determine the ideal cutoff points for BNP and NT-proBNP tests because we did not have the raw data to map out ROC curves. To determine whether there is a single threshold or a few important BNP or NT-proBNP thresholds (e.g., age dependent), further evaluation in prespecified groups of larger numbers of patients is needed.

\section{Conclusions}

This systematic review and meta-analysis suggests that an elevated BNP or NT-proBNP level may prove to be a powerful predictor of mortality in patients with sepsis. This test appears to represent a rapid and relatively inexpensive method to enhance mortality prediction in sepsis. Future larger and more adequately powered prospective studies are warranted to clarify the assay standardization, the optimal cut-off, and the prognostic value of BNPs in conjunction with other biomarkers.

\section{Key messages}

- The literature shows that an elevated BNP or NTproBNP level is a powerful predictor of mortality in patients with sepsis.

- This test appears to represent a rapid and relatively inexpensive method to enhance mortality prediction in sepsis.

- Larger adequately powered prospective studies are warranted to clarify the assay standardization, the optimal cut-off, and the prognostic value of BNPs in conjunction with other biomarkers in future.

\section{Additional material}

Additional file 1: The Original Quality Assessment of Diagnostic

Accuracy Studies Checklist

\section{Abbreviations}

BNP: brain natriuretic peptide; NT-proBNP: N-terminal pro-B-type natriuretic peptide; ICU: intensive care unit; OR: odds ratio; $\mathrm{Cl}$ : confidence interval; ROC: receiver operating characteristic; APACHE: acute physiology and chronic health evaluation; SOFA: sequential organ failure assessment.

\section{Acknowledgements}

We sincerely thank all authors who provided additional particulars to their published data.

\section{Author details}

${ }^{1}$ Department of Anesthesiology and Critical Care, Changhai Hospital, Second Military Medical University, Shanghai, China. ${ }^{2}$ Department of Nursing, Changhai Hospital, Second Military Medical University, Shanghai, China.

${ }^{3}$ Department of Anesthesiology, General Hospital of Jinan Military Command, Jinan, China.

\section{Authors' contributions}

Study concept and design: FW, YW, LT, JL and XD. Acquisition of data: FW, YW and LT. Analysis and interpretation of data: WZ, FC, LB and TX. Drafting of the manuscript: FW, YW and LT. Critical revision of the manuscript for important intellectual content: $J$ and XD. Statistical analysis: FW and YW. Administrative, technical, and material support: WZ, FC, LB and TX. Study supervision: $J$ and $X D$. All authors have read and approved the manuscript for publication. 


\section{Competing interests}

The authors declare that they have no competing interests.

Received: 24 March 2012 Revised: 26 April 2012 Accepted: 6 May 2012 Published: 6 May 2012

\section{References}

1. Angus DC, Linde-Zwirble WT, Lidicker J, Clermont G, Carcillo J, Pinsky MR: Epidemiology of severe sepsis in the United States: analysis of incidence, outcome, and associated costs of care. Crit Care Med 2001, 29:1303-1310.

2. Gullo A, Bianco N, Berlot G: Management of severe sepsis and septic shock: challenges and recommendations. Crit Care Clin 2006, 22:489-501.

3. Hotchkiss RS, Karl IE: The pathophysiology and treatment of sepsis. N Engl J Med 2003, 348:138-150

4. Kumar A, Roberts D, Wood KE, Light B, Parrillo JE, Sharma S, Suppes R, Feinstein D, Zanotti S, Taiberg L, Gurka D, Kumar A, Cheanq M: Duration of hypotension before initiation of effective antimicrobial therapy is the critical determinant of survival in human septic shock. Crit Care Med 2006, 34:1589-1596.

5. Rangel-Frausto MS, Pittet D, Costigan M, Hwang T, Davis CS, Wenzel RP: The natural history of the systemic inflammatory response syndrome (SIRS). A prospective study. JAMA 1995, 273:117-123.

6. Zambon M, Ceola M, Almeida-de-Castro R, Gullo A, Vincent JL: Implementation of the Surviving Sepsis Campaign guidelines for severe sepsis and septic shock: we could go faster. J Crit Care 2008, 23:455-460.

7. Levin ER, Gardner DG, Samson WK: Natriuretic peptides. N Engl J Med 1998, 339:321-328

8. Goetze JP, Christoffersen C, Perko M, Arendrup H, Rehfeld JF, Kastrup J, Nielsen LB: Increased cardiac BNP expression associated with myocardial ischemia. FASEB J 2003, 17:1105-1107.

9. Vanderheyden M, Bartunek J, Goethals M: Brain and other natriuretic peptides: molecular aspects. Eur J Heart Fail 2004, 6:261-268.

10. Tang WH, Francis GS, Morrow DA, Newby LK, Cannon CP, Jesse RL, Storrow AB, Christenson RH, Apple FS, Ravkilde J, Wu AH, National Academy of Clinical Biochemistry Laboratory Medicine: National Academy of Clinical Biochemistry Laboratory Medicine practice guidelines: Clinical utilization of cardiac biomarker testing in heart failure. Circulation 2007, 116:e99-109.

11. Kragelund C, Gronning B, Kober L, Hildebrandt P, Steffensen R: N-terminal pro-B-type natriuretic peptide and long-term mortality in stable coronary heart disease. N Engl J Med 2005, 352:666-675.

12. De Lemos JA, Morrow DA, Bentley JH, Omland T, Sabatine MS, McCabe CH, Hall C, Cannon CP, Braunwald E: The prognostic value of B-type natriuretic peptide in patients with acute coronary syndromes. $N$ Engl $]$ Med 2001, 345:1014-1021.

13. Pieralli F, Olivotto I, Vanni S, Conti A, Camaiti A, Targioni G, Grifoni S, Berni $\mathrm{G}$ : Usefulness of bedside testing for brain natriuretic peptide to identify right ventricular dysfunction and outcome in normotensive patients with acute pulmonary embolism. Am J Cardiol 2006, 97:1386-1390.

14. Karthikeyan G, Moncur RA, Levine O, Heels-Ansdell D, Chan MT, AlonsoCoello P, Yusuf S, Sessler D, Villar JC, Berwanger O, McQueen M, Mathew A, Hill S, Gibson S, Berry C, Yeh HM, Devereaux PJ: Is a pre-operative brain natriuretic peptide or $\mathrm{N}$-terminal pro-B-type natriuretic peptide measurement an independent predictor of adverse cardiovascular outcomes within 30 days of noncardiac surgery? A systematic review and meta-analysis of observational studies. J Am Coll Cardiol 2009, 54:1599-1606.

15. Stroup DF, Berlin JA, Morton SC, Olkin I, Williamson GD, Rennie D, Moher D, Becker BJ, Sipe TA, Thacker SB: Meta-analysis of observational studies in epidemiology: a proposal for reporting. Meta-analysis Of Observational Studies in Epidemiology (MOOSE) group. JAMA 2000, 283:2008-2012.

16. Landis JR, Koch GG: The measurement of observer agreement for categorical data. Biometrics 1977, 33:159-174.

17. Whiting P, Rutjes AW, Reitsma JB, Bossuyt PM, Kleijnen J: The development of QUADAS: a tool for the quality assessment of studies of diagnostic accuracy included in systematic reviews. BMC Med Res Methodol 2003, 3.25 .
18. Zamora J, Abraira V, Muriel A, Khan K, Coomarasamy A: Meta-DiSc: a software for meta-analysis of test accuracy data. BMC Med Res Methodol 2006, 6:31.

19. Deville WL, Buntinx F, Bouter LM, Montori VM, de Vet $H C$, van der Windt DA, Bezemer PD: Conducting systematic reviews of diagnostic studies: didactic guidelines. BMC Med Res Methodol 2002, 2:9.

20. DerSimonian R, Laird N: Meta-analysis in clinical trials. Control Clin Trials 1986, 7:177-188.

21. Higgins JP, Thompson SG, Deeks JJ, Altman DG: Measuring inconsistency in meta-analyses. BMJ 2003, 327:557-560.

22. Perman SM, Chang AM, Hollander JE, Gaieski DF, Trzeciak S, Birkhahn R, Otero R, Osborn TM, Moretti E, Nguyen HB, Gunnerson KJ, Milzman D, Goyal M, Cairns CB, Ngo L, Rivers EP, Shapiro NI: Relationship between Btype natriuretic peptide and adverse outcome in patients with clinical evidence of sepsis presenting to the emergency department. Acad Emerg Med 2011, 18:219-222.

23. Sturgess DJ, Marwick TH, Joyce C, Jenkins C, Jones M, Masci P, Stewart D, Venkatesh B: Prediction of hospital outcome in septic shock: a prospective comparison of tissue Doppler and cardiac biomarkers. Crit Care 2010, 14:R44.

24. Zhao HY, An YZ, Liu F: Prognostic values of B-type natriuretic peptide in severe sepsis and septic shock. Zhongguo Wei Zhong Bing Ji Jiu Yi Xue 2009, 21:293-295.

25. Chen Y, Li C: Prognostic significance of brain natriuretic peptide obtained in the ED in patients with SIRS or sepsis. Am J Emerg Med 2009, 27:701-706.

26. Yucel T, Memis D, Karamanlioglu B, Süt N, Yuksel M: The prognostic value of atrial and brain natriuretic peptides, troponin I and C-reactive protein in patients with sepsis. Exp Clin Cardiol 2008, 13:183-188.

27. Post F, Weilemann LS, Messow CM, Sinning C, Münzel T: B-type natriuretic peptide as a marker for sepsis-induced myocardial depression in intensive care patients. Crit Care Med 2008, 36:3030-3037.

28. Varpula M, Pulkki K, Karlsson S, Ruokonen E, Pettilä V, FINNSEPSIS Study Group: Predictive value of N-terminal pro-brain natriuretic peptide in severe sepsis and septic shock. Crit Care Med 2007, 35:1277-1283.

29. Mokart D, Sannini A, Brun JP, Faucher M, Blaise D, Blache JL, Faucher C: Nterminal pro-brain natriuretic peptide as an early prognostic factor in cancer patients developing septic shock. Crit Care 2007, 11:R37.

30. Ueda S, Nishio K, Akai Y, Fukushima H, Ueyama T, Kawai Y, Masui K, Yoshioka A, Okuchi K: Prognostic value of increased plasma levels of brain natriuretic peptide in patients with septic shock. Shock 2006, 26:134-139.

31. Roch A, Allardet-Servent J, Michelet P, Oddoze C, Forel JM, Barrau K, Loundou A, Perrin G, Auffray JP, Portugal H, Papazian L: NH2 terminal probrain natriuretic peptide plasma level as an early marker of prognosis and cardiac dysfunction in septic shock patients. Crit Care Med 2005, 33:1001-1007.

32. Brueckmann M, Huhle G, Lang S, Haase KK, Bertsch T, Weiss C, Kaden JJ, Putensen C, Borggrefe M, Hoffmann U: Prognostic value of plasma Nterminal pro-brain natriuretic peptide in patients with severe sepsis. Circulation 2005, 112:527-534.

33. Charpentier J, Luyt CE, Fulla Y, Vinsonneau C, Cariou A, Grabar S, Dhainaut JF, Mira JP, Chiche JD: Brain natriuretic peptide: A marker of myocardial dysfunction and prognosis during severe sepsis. Crit Care Med 2004, 32:660-665.

34. Maeder M, Ammann P, Kiowski W, Rickli H: B-type natriuretic peptide in patients with sepsis and preserved left ventricular ejection fraction. Eur $J$ Heart Fail 2005, 7:1164-1167.

35. Court O, Kumar A, Parrillo JE: Clinical review: Myocardial depression in sepsis and septic shock. Crit Care 2002, 6:500-508.

36. Tomaru Ki K, Arai M, Yokoyama T, Aihara Y, Sekiguchi Ki K, Tanaka T, Nagai R, Kurabayashi M: Transcriptional activation of the BNP gene by lipopolysaccharide is mediated through GATA elements in neonatal rat cardiac myocytes. J Mol Cell Cardiol 2002, 34:649-659.

37. He Q, LaPointe MC: Interleukin-1 beta regulation of the human brain natriuretic peptide promoter involves Ras-, Rac-, and p38 kinasedependent pathways in cardiac myocytes. Hypertension 1999, 33:283-289.

38. Kuwahara K, Saito Y, Harada M, Ishikawa M, Ogawa E, Miyamoto Y, Hamanaka I, Kamitani S, Kajiyama N, Takahashi N, Nakagawa O, Masuda I, Nakao K: Involvement of cardiotrophin-1 in cardiac myocyte-nonmyocyte 
interactions during hypertrophy of rat cardiac myocytes in vitro. Circulation 1999, 100:1116-1124.

39. Phua J, Lim TK, Lee KH: B-type natriuretic peptide: issues for the intensivist and pulmonologist. Crit Care Med 2005, 33:2094-2013.

40. Maeder M, Fehr T, Rickli H, Ammann P: Sepsis-associated myocardial dysfunction: diagnostic and prognostic impact of cardiac troponins and natriuretic peptides. Chest 2006, 129:1349-1366.

41. Kandil Emad, Burack Joshua, Sawas Ahmed, Bibawy Haidy, Schwartzman Alex, Zenilman Michael E, Bluth Martin H: B-type natriuretic peptide: a biomarker for the diagnosis and risk stratification of patients with septic shock. Arch Surg 2008, 143:242-6.

42. Rivers Emanuel P: Clinical Utility of B-Type Natriuretic Peptide in Early Severe Sepsis and Septic Shock. I Intensive Care Med 2007, 22:363-73.

43. Giamarellos-Bourboulis EJ, Tsangaris I, Kanni T, Mouktaroudi M, Pantelidou I, Adamis G, Atmatzidis S, Chrisofos M, Evangelopoulou V, Frantzeskaki F, Giannopoulos P, Giannikopoulos G, Gialvalis D, Gourgoulis GM, Kotzampassi K, Katsifa K, Kofinas G, Kontopidou F, Koratzanis G, Koulouras V, Koutsikou A, Koupetori M, Kritselis I, Leonidou L, Mega A, Mylona V, Nikolaou H, Orfanos S, Panagopoulos P, Paramythiotou E, Hellenic Sepsis Study Group, et al: Procalcitonin as an early indicator of outcome in sepsis: a prospective observational study. J Hosp Infect 2011, 77:58-63.

44. Choon-ngarm T, Partpisanu P: Serum cardiac troponin-T as a prognostic marker in septic shock. J Med Assoc Thai 2008, 91:1818-1821.

45. Mehta NJ, Khan IA, Gupta V, Jani K, Gowda RM, Smith PR: Cardiac troponin I predicts myocardial dysfunction and adverse outcome in septic shock. Int J Cardiol 2004, 95:13-17.

46. Pierrakos C, Vincent IL: Sepsis biomarkers: a review. Crit Care 2010, 14:R15.

47. Omland T: Advances in congestive heart failure management in the intensive care unit: B-type natriuretic peptides in evaluation of acute heart failure. Crit Care Med 2008, 36:S17-27.

48. Prontera C, Zaninotto M, Giovannini S, Zucchelli GC, Pilo A, Sciacovelli L, Plebani , Clerico A: Proficiency testing project for brain natriuretic peptide (BNP) and the N-terminal part of the propeptide of BNP (NTproBNP) immunoassays: the CardioOrmocheck study. Clin Chem Lab Med 2009, 47:762-768.

49. Hoste EA, Lameire NH, Vanholder RC, Benoit DD, Decruyenaere JM, Colardyn FA: Acute renal failure in patients with sepsis in a surgical ICU: predictive factors, incidence, comorbidity, and outcome. J Am Soc Nephrol 2003, 14:1022-1030.

50. Yegenaga I, Hoste E, Van Biesen W, Vanholder R, Benoit D, Kantarci G, Dhondt A, Colardyn F, Lameire N: Clinical characteristics of patients developing ARF due to sepsis/systemic inflammatory response syndrome: Results of a prospective study. Am J Kidney Dis 2004 43:817-824.

51. Goei D, Schouten O, Boersma E, Welten GM, Dunkelgrun M, Lindemans J van Gestel YR, Hoeks SE, Bax JJ, Poldermans D: Influence of renal function on the usefulness of N-terminal pro-B-type natriuretic peptide as a prognostic cardiac risk marker in patients undergoing noncardiac vascular surgery. Am J Cardiol 2008, 101:122-126.

doi:10.1186/cc11331

Cite this article as: Wang et al: Brain natriuretic peptide for prediction of mortality in patients with sepsis: a systematic review and metaanalysis. Critical Care 2012 16:R74

\section{Submit your next manuscript to BioMed Central and take full advantage of:}

- Convenient online submission

- Thorough peer review

- No space constraints or color figure charges

- Immediate publication on acceptance

- Inclusion in PubMed, CAS, Scopus and Google Scholar

- Research which is freely available for redistribution

Submit your manuscript at www.biomedcentral.com/submit
C Biomed Central 